\title{
THE ATTITUDES AND HABITS OF PATIENTS TOWARD USE OF HERBAL DRUGS
}

\author{
Milica Stanojevic1, Jagoda Nikolic1, Marija Jovanovic1, Aleksandar Kocovic ${ }^{2}$, Milos Milosavljevic'2, Milica Milosavljevic ${ }^{3}$ \\ ${ }^{1}$ College of Applied Health Sciences Cuprija, Cuprija, Serbia
}

${ }^{2}$ Faculty of Medical Sciences, Department of Pharmacy, University of Kragujevac, Kragujevac, Serbia ${ }^{3}$ Faculty of Medicine, University of University of Pristina - Kosovska Mitrovica, Kosovska Mitrovica, Serbia

\section{STAVOVI I NAVIKE PACIJENATA O KORIŠĆENJU BILJNIH LEKOVA}

\author{
Milica Stanojević1, Jagoda Nikolić1, Marija Jovanović1, Aleksandar Kočovićn , Miloš Milosavljević2 ${ }^{\text {, Milica Milosavljević }}{ }^{3}$ \\ IVisoka medicinska škola strukovnih studija Ćuprija, Ćuprija \\ ${ }^{2}$ Fakultet medicinskih nauka, Katedra za farmaciju, Univerzitet u Kragujevcu, Kragujevac \\ ${ }^{3}$ Medicinski fakultet, Univerzitet u Prištini - Kosovska Mitrovica, Kosovska Mitrovica
}

\section{ABSTRACT}

Objective. The aim of study was to examine the factors associated with the use of herbal drugs among patients in Serbia, as well as to assess the attitudes and habits of patients toward the use of herbal drugs.

Methods. The study was designed as an observational, cross-sectional study. The research was conducted during February 2018 in six community pharmacies across the municipalities of Despotovac and Cuprija. Study population consisted of adult volunteers of both genders and over 18 years of age who had purchased drugs in one of the six pharmacies involved in the study. Participants filled out the semi-structured questionnaires which had been specifically designed for purposes of this research. The questionnaire consisted of two parts. The first part comprised five questions relating to socio-demographic characteristics of participants, while the second part of the questionnaire was composed of eight questions concerning the use of herbal products. The study data were analyzed by descriptive and analytical statistics by SPSS statistical program.

Results. There were 190 participants in total. The average age of the study subjects was $47.83 \pm 15.9$ years (the youngest was 18, while the oldest was 87 years old). Some form of herbal product was used by 145 (76.3\%) participants. The most common reasons for the use of herbal drugs were common cold (22.6\%), improving the digestion (8.9\%), stimulation of immune system (7.5\%), dermatological problems $(7.5 \%)$, cough $(4.8 \%)$ and rheumatic complaints $(4.8 \%)$. The most frequently participants gained information on use of herbal drugs from pharmacists (26.9\%), from sources provided by Internet (21.0\%), from their physicians (11.8\%) and from family members and friends (10.8\%). Of the total number $67.7 \%$ of participants considered herbal drugs to be completely safe for use. Slightly more than half of the study subjects (52.7\%) gave information on using the herbal drug to their physicians. The binary logistic regression analyses showed that herbal drugs were more commonly used by younger women, with a higher school or university degree who prefer to use herbal medicines compared to other drugs.

Conclusion. The results of our study have shown that herbal drugs had been more commonly used by younger women, with a higher school degree or university degree, and who declared that they preferred to use herbal drugs in relation to other drugs.

Key words: complementary therapies; phytotherapy; pharmacies.

\section{SAŽETAK}

Cilj. Cilj studije je bio procena faktora povezanih sa upotrebom biljnih lekova kod pacijenata u Srbiji, stavova $i$ navika koje pacijenti imaju prema upotrebi biljnih lekova.

Metode. Studija je dizajnirana kao opservaciona studija preseka. Istraživanje je sprovedeno u februaru 2018. godine $u$ šest javnih apoteka na teritoriji opština Despotovac $i$ Ćuprija. Studijsku populaciju činili su dobrovoljci oba pola, starosti preko 18 godina, koji su kupovali lekove u jednoj od šest apoteka obuhvaćenih ovim istraživanjem. Ispitanici su popunjavali polustrukturirani upitnik koji je bio specijalno dizajniran za potrebe ovog istraživanja. Upitnik se sastojao iz dva dela. Prvi deo je imao pet pitanja u vezi sa sociodemografskim karakteristikama ispitanika, dok je drugi deo upitnika imao osam pitanja koja su se odnosila na upotrebu biljnih lekova. Studijski podaci su analizirani odgovarajućim metodama deskriptivne i analitičke statistike pomoću SPSS softverskog programa.

Rezultati. Ukupno je bilo 190 ispitanika. Prosečna starost ispitanika bila je 47,83 $\pm 15,9$ godina (najmladi ispitanik imao je 18, a najstariji 89 godina). Neki oblik biljnog preparata koristilo je 145 (76,3\%) ispitanika. Najčešći razlozi za upotrebu biljnih lekova bili su prehlada (22,6\%), poboljšanje varenja (8,9\%), stimulacija imunskog sistema (7,5\%), dermatološki problemi (7,5\%), kašalj (4,8 $\%$ i reumatske tegobe $(4,8 \%)$. Pokazano je da se ispitanici o biljnim lekovima najčešće informišu direktno od farmaceuta (26,9\%), internetom (21,0\%), direktno od lekara $(11,8 \%)$, odnosno članova porodice i prijatelja (10,8\%). Od ukupnog broja ispitanika, 67,7\% smatralo je da su biljni lekovi u potpunosti bezbedni za upotrebu. Nešto više od polovine ispitanika (52,7\%) informiše svoje lekare o upotrebi biljnog leka. Logistička regresiona analiza pokazala je da biljne lekove češće koriste mlađe žene, sa završenom višom školom ili fakultetom, koje radije koriste biljne lekove $u$ odnosu na konvencionalne medicinske proizvode.

Zaključak. Rezultati naše studije su pokazali da su biljne lekove češće koristile žene mlađe životne dobi, sa završenom višom školom ili fakultetom, a koje su se izjasnile da radije koriste biljne lekove u odnosu na druge lekove.

Ključne reči: komplementarne terapije; fitoterapija; apoteke. 


\section{INTRODUCTION}

According to the Serbian law on medicines and medical devices, herbal drug is any medicinal product whose active ingredients are exclusively one or more plant substances or one or more herbal preparations or one or more plant substances in combination with one or more herbal preparations (1). In Serbia, herbal drugs are mainly OTC preparations that are available to patients in community pharmacies (2). The use of self-medication with herbal drugs is rapidly growing all over the world (3). According to the World Health Organization (WHO), 80\% of the population living in rural areas in developing countries use some form of non-conventional medicine, whereby the use of herbal drugs is particularly popular (4). However, surprising data suggest that there is an undeniable trend of increasing the use of herbal drugs in many developing and industrialized countries (5). The increased frequency of self-medication with herbal drugs could have serious consequences. Incorrect self-diagnosis, masking of a severe diseases, occurrences of adverse reactions and severe drug-drug interactions are the most important problems related to the herbal drugs selfmedication. Besides that, there is potential risk of incorrectly identified medical plants or contamination of herbs with pesticides, heavy metals or radioactivity, making herbal drugs especially dangerous (6).

There are many different reasons for increased use of herbal drugs and other OTC medicines. The legal regulations enable the unhindered advertising of OTC products through the means of public information (7-8). Also, there is a general community perception that herbal drugs are completely safe (9). Apart from this, modern trends are such that the use of dietary supplements, healthy foods and herbal and another OTC drugs seems benevolent, and therefore it is not surprising that the popularity and consumption of these products also increases (10). This trend also indicates that patients are not satisfied with the official treatment programs, so more often they prefer self-medication. In Serbia, patients complain on publicly funded health services due to many reasons. One of the most important reasons is certainly prolonged waiting for a medical examination (2). In addition, to gain the information on the illnesses and possibilities of treatment, patients nowadays rely mainly on Internet, and therefore they resort to self-medication and the purchase of medicines in pharmacies without a visit to a doctor (11).

Although some of these socio-demographic and health service related factors are well-known, there is still a need for of exploring the additional factors in terms of their contribution to the increased use of herbal drugs. It seems that the relevance of the factor related to the source of information of patients about herbal drugs has not been investigated sufficiently. Therefore, the aim of this study will be to examine the factors associated with the use of herbal drugs among patients in Serbia, as well as the attitudes and habits of patients towards the use of herbal drugs.

\section{PATIENTS AND METHODS}

\section{STUDY POPULATION}

The clinical research was designed as observational, cross-sectional study. The overall consecutive sample for this research consisted of community-dwelling adult persons (aged 18 years or above) of both sexes. All participants were recruited in six community pharmacies across municipalities of Despotovac and Ćuprija. The research was carried out during February 2018. The participation in study was voluntary and the employees in the pharmacies did not exert any pressure or conditioned the potential respondents in any other way. Also, no one of participants was enrolled without signing the informed consent. All relevant data were gathered via the semistructured questionnaires. Participants filled out their questionnaires by themselves, and any assistance was provided by study investigators. Each participant who gave incomplete and inaccurate data was excluded from further analyses.

\section{QUESTIONNAIRE}

The questionnaire consisted of two parts. The first part had five questions about socio-demographic characteristics of participants (age, gender, level of education, profession of participant and their work status), while the second part of the questionnaire included eight questions with respect to use of herbal products (do they use herbal products, which type of product they use, what is the purpose of their use, do they prefer them in comparison with other drugs, do they consider herbal products as safe for use, how they are informed about herbal products, do they inform general practitioner about use of herbal products, and did they have any inconvenience during use of herbal products).

\section{DATA ANALYSIS}

The study data were analyzed by descriptive statistics and presented in tables and graphs. Mean was used as a measure of central tendency and standard deviation as a measure of dispersion for continuous variables. Values of categorical variables were presented as percentages. Significance of differences in the rates of categorical variables was tested by the Chi-square test, or in case of low prevalence of particular categories by Fisher's test. Null hypothesis was considered to be true if probability of difference was larger than 0.05 . Influence of participants' 
characteristics on frequent use of herbal products was evaluated by univariate and multivariate binary logistic regression analysis. The results were shown as crude and adjusted odds ratios (ORs) with corresponding 95\% confidence intervals (CI). All calculations were performed by statistical program for social sciences (SPSS version 18).

\section{RESULTS}

There were 190 participants in total. The average age of the participants was $47.83 \pm 15.9$ years. The oldest participant was 89 and the youngest 18 years old. Some form of herbal product was used by 145 (76.3\%) participants. Baseline socio-demographic characteristics of the participants and their influence on the use of herbal products are shown in Table 1.

Professions of participants are shown in Figure 1. Significant difference in the use of herbal remedies depending on profession was not observed $\left(\chi^{2}=8.782\right.$, $p$ $=0.642$ ).

When it comes to the type of herbal drugs, herbal teas $(42.8 \%)$, tablets $(9.0 \%)$, syrups $(4.1 \%)$, creams $(4.1 \%)$ and drops $(3.4 \%)$ were the most commonly used. As a special group, oil extract of St. John's wort was used by $4.8 \%$ of the participants. Also, participants were mainly used combination of herbal teas and syrups $(6.2 \%)$ and herbal teas and creams $(5.5 \%)$. Three or more drugs combine $9.0 \%$ of subjects, and most common triple combination was herbal teas, syrups and creams (3.4\%).

The most common reasons for the use of herbal drugs were common cold (22.6\%), improving digestion (8.9\%), stimulation of immune system $(7.5 \%)$, dermatological problems $(7.5 \%)$, cough $(4.8 \%)$ and rheumatic complaints $(4.8 \%)$.
Majority of participants $(57.4 \%)$ preferred herbal drugs in comparison with other drugs. Also, those who preferred the use of herbal drugs were more likely to use them in comparison to subjects who did not prefer herbal medications $(\chi 2=33.667, \mathrm{p}<0.001)$.

Participants were most frequently informed about herbal drugs by pharmacists $(26.9 \%)$, on the Internet $(21.0 \%)$, by their physician $(11.8 \%)$ and family members and friends $(10.8 \%)$. There was no significant difference in the use of herbal drugs, depending on the source of information about them $\left(\chi^{2}=19.818, p=0.031\right)$. Herbal drugs were most often used by those participants who had gained information by pharmacists.

Of total, $67.7 \%$ of participants considered herbal drugs as completely safe for use. There was no statistically significant difference in the use of herbal drugs depending on the participants' opinion on their safety $\left(\chi^{2}=1.102, p=\right.$ 0.294).

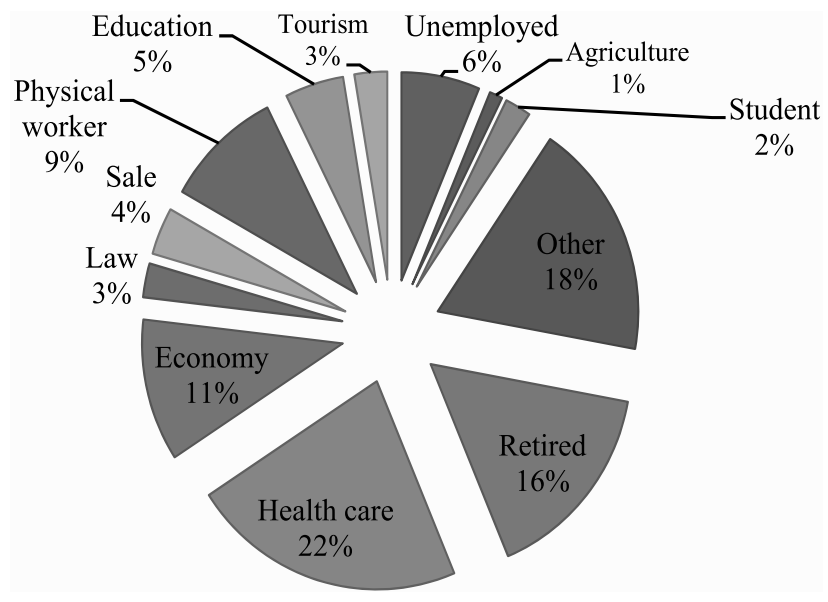

Figure 1. Professions of participants

Table 1. Baseline characteristics of the participants and their influence on the use of herbal products

\begin{tabular}{|c|c|c|c|c|c|}
\hline & \multicolumn{4}{|c|}{ Herbal product use } & \multirow{3}{*}{$\chi^{2}$ test (p-value) } \\
\hline & \multicolumn{2}{|c|}{ Yes } & \multicolumn{2}{|c|}{ No } & \\
\hline & $\mathrm{n}$ & $\%$ & $\mathrm{n}$ & $\%$ & \\
\hline Age (M+SD) & \multicolumn{2}{|c|}{$46.28 \pm 15.57$} & \multicolumn{2}{|c|}{$52.80 \pm 16.25$} & $\mathrm{t}=2.428^{\#}(\mathrm{p}=0.016)^{*}$ \\
\hline \multicolumn{6}{|l|}{ Gender } \\
\hline Male & 42 & 65.6 & 22 & 34.4 & \multirow{2}{*}{$6.103(\mathrm{p}=0.013)^{*}$} \\
\hline Female & 103 & 81.7 & 23 & 18.3 & \\
\hline \multicolumn{6}{|l|}{ Level of education } \\
\hline Primary school & 17 & 56.7 & 13 & 43.3 & \multirow{4}{*}{$8.973(\mathrm{p}=0.030)^{*}$} \\
\hline Secondary school & 73 & 76.8 & 22 & 23.2 & \\
\hline Higher school & 25 & 86.2 & 4 & 13.8 & \\
\hline University & 30 & 83.3 & 6 & 16.7 & \\
\hline
\end{tabular}


Table 2. Crude and adjusted odds ratio for characteristics associated with the frequent use of herbal remedies.

\begin{tabular}{|c|c|c|c|c|}
\hline Variable & $\begin{array}{c}\text { Crude OR } \\
(95 \% \mathrm{CI})\end{array}$ & $\mathrm{p}$ & $\begin{array}{c}\text { Adjusted OR } \\
(95 \% \mathrm{CI})\end{array}$ & $\mathrm{p}$ \\
\hline \multicolumn{5}{|l|}{ Gender } \\
\hline Male & 1 & & 1 & \\
\hline Female & $\begin{array}{c}2.346 \\
(1.181-4.657) \\
\end{array}$ & $0.015^{*}$ & $\begin{array}{c}2.453 \\
(1.185-5.076) \\
\end{array}$ & $0.016^{*}$ \\
\hline Age (years) & $\begin{array}{c}0.975 \\
(0.954-0.996) \\
\end{array}$ & $0.018^{*}$ & $\begin{array}{c}0.990 \\
(0.962-1.018) \\
\end{array}$ & 0.470 \\
\hline \multicolumn{5}{|l|}{ Level of education } \\
\hline Elementary school & 1 & & 1 & \\
\hline High school & $\begin{array}{c}2.537 \\
(1.068-6.028) \\
\end{array}$ & $0.035^{*}$ & $\begin{array}{c}2.193 \\
(0.813-5.913) \\
\end{array}$ & 0.121 \\
\hline Higher school & $\begin{array}{c}4.779 \\
(1.330-17.110)\end{array}$ & $0.017^{*}$ & $\begin{array}{c}3.996 \\
(0.960-16.636)\end{array}$ & 0.057 \\
\hline University & $\begin{array}{c}3.824 \\
(1.228-11.904)\end{array}$ & $0.021^{*}$ & $\begin{array}{c}3.494 \\
(0.918-13.306)\end{array}$ & 0.067 \\
\hline \multicolumn{5}{|l|}{ Work status } \\
\hline Employed & 1 & & 1 & \\
\hline Unemployed & $\begin{array}{c}0.526 \\
(0.148-1.866) \\
\end{array}$ & 0.320 & $\begin{array}{c}0.924 \\
(0.221-3.863) \\
\end{array}$ & 0.914 \\
\hline Inactive & $\begin{array}{c}0.550 \\
(0.242-1.254) \\
\end{array}$ & 0.155 & $\begin{array}{c}0.946 \\
(0.326-2.743) \\
\end{array}$ & 0.918 \\
\hline \multicolumn{5}{|l|}{ Prefer herbal drugs } \\
\hline No & 1 & & 1 & \\
\hline Yes & $\begin{array}{c}8.889 \\
(3.951-19.996) \\
\end{array}$ & $0.000^{*}$ & $\begin{array}{c}9.110 \\
(3.801-21.836) \\
\end{array}$ & $0.000^{*}$ \\
\hline \multicolumn{5}{|c|}{ Beliefs of safety of herbal drugs } \\
\hline No & 1 & & 1 & \\
\hline Yes & $\begin{array}{c}1.469 \\
(0.715-3.020) \\
\end{array}$ & 0.295 & $\begin{array}{c}2.043 \\
(0.904-4.616) \\
\end{array}$ & 0.086 \\
\hline
\end{tabular}

OR - odds ratio; CI - confidence interval; $\mathrm{p}$ - significance level; *-Significant difference; \# - adjusted for gender, age, level of education and work status.

More than half of the participants (52.7\%) informed their physicians about the use of a herbal drug. Also, the vast majority of participants $(97.2 \%)$ never experienced any inconveniences or adverse reactions after the application of herbal drugs. The use of the herbal drugs did not differ depending on the occurrence of an inconvenience or an adverse reaction $\left(\chi^{2}=1.268, \mathrm{p}=\right.$ $0.260)$.

The results of the both univariate and multivariate binary logistic regression are shown in the Table 2 . The univariate model distinguished gender $(\mathrm{p}=0.015)$, age ( $\mathrm{p}$ $=0.018)$, level of education $(\mathrm{p}=0.035$ for secondary school, 0.017 for higher school and 0.021 for university), and preferring herbal drugs in relation to other drugs and products $(p=0.000)$ in terms of important influence on the frequent use of herbal drugs. After adjustment for potential confounders and other independent variables it was shown that gender $(\mathrm{OR}=2.453 ; 95 \% \mathrm{CI}=1.185-5.076)$ and the preferences for the herbal drugs $(\mathrm{OR}=9.110 ; 95 \% \mathrm{CI}=$ 3.801-21.836) were significantly associated with the observed outcome. The results of the study showed that herbal drugs had been more commonly used by younger women, with a higher school degree or faculty degree that preferred herbal drugs compared to the other drugs.

\section{DISCUSSION}

In our cross-sectional study we have analyzed the attitudes and habits of patients according to the use of herbal drugs in the prevention and treatment of different diseases. In this study, we have shown that patients mostly think that herbal drugs are completely safe. Therefore, they more often decide to use herbal drugs than other types of drugs. Patients have declared themselves using herbal drugs for the prevention and treatment of different diseases, such as common cold, improving digestion, stimulation of immune system, dermatological problems, cough and rheumatic complaints. The most common type of herbal drugs used by our participants were teas, and then tablets, syrups, creams, drops and oil extract of St. 
John's wort. Our patients mostly consult their pharmacists and physicians about the use of herbal drugs, but not a small number of patients are informed about herbal drugs on the Internet and from their relatives and acquaintances. Also, almost a half of our patients reported that they do not inform their physicians about the use of herbal remedies. Despite all this, the vast majority of our patients who use herbal preparations did not experience any inconvenience during the use of herbal remedies

A great problem in self-medication with herbal drugs is the fact that the patients consider that the herbal preparations are completely safe and therefore they prefer to use them at the expense of conventional drugs (9). Approximately $70 \%$ of our patients showed such attitude towards use of herbal drugs, which is in accordance with the results of authors in Malaysia (12) and Lebanon (13). It is particularly interesting that, despite the significant sociological and cultural differences between patients who participated in our study and patients in Malaysia and Lebanon, the attitude towards herbal medicines is similar. In study which was conducted in Serbia in 2011 (14), the percentage of patients who considered herbal drugs as harmless was even greater, achieving the rate of $-73.3 \%$. Precisely, due to such attitude, that was observed in about of $60 \%$ of our patients, they were more likely to use herbal drugs in comparison with conventional medicines. Such attitudes and behavior can produce serious consequences for the health of potential users of herbal preparations, since herbal drugs could be contaminated with heavy metals or radioactive elements; also, it is known that herbal drugs could have serious adverse effects and serious drug-drug interactions (6).

When it comes to indications for the use of herbal drugs, our results are also in accordance with results of other authors. In study conducted in Czech Republic during 2007 (15), the patients used herbal drugs for cold, stomach or intestinal illnesses and immunity and regeneration support, which is very similar with indications given by our patients. It is particularly interesting that almost $5 \%$ of our patients pointed out that they use oil extract of St. John's wort, as a dermatological preparation. Despite the existence of significant cultural differences, the authors in Saudi Arabia also reported significant percentage $(3.5 \%)$ of herbal drug users had applied the preparations of this plant (16). Preparations of St. John's wort could interact with a large number of different drugs (17-18), even when we talk about dermatological preparations in form of oil extract (19).

Approximately $90 \%$ of patients in this study conducted in Serbia in 2011 (14) did not consider the importance of informing their physicians or pharmacists about the use of herbal drugs. In our study, the percentage of patients which inform their physicians about the use of herbal drugs $(52.7 \%)$ is different in comparison to results of other authors. In the study conducted in Czech Republic (15) $56.6 \%$ of patients did not inform their physicians about the use of herbal drugs, in the study conducted in India 59.9\% (20), in Taiwan even $75.4 \%$ (21); in the study (22) conducted in United Kingdom vast majority of patients did not report the use of herbal drug to their physician. Besides the risk of drug-drug interactions, this kind of behavior is particularly dangerous from the aspect of adverse effects. It is known that herbal drugs could have serious side effects, such as hepatotoxicity (23-24).

The patients in our study listed pharmacists $(26.9 \%)$, Internet $(21.0 \%)$, physicians $(11.8 \%)$ and family members and friends $(10.8 \%)$ as sources of information on herbal drugs. In the study conducted in Lebanon (13) the patients pointed out that information on herbal medicines is most often obtained from friends and relatives. On the other hand, literature, mass media and family tradition were the most important sources for information about herbal drugs for patients in the study conducted in Czech Republic (15). Herbal drug users need reliable and accessible information for safe and appropriate use of herbal drugs. All of these sources of information have serious limitations when it comes to adequate advice for the use of herbal drugs (25). The information about herbal drugs which could be found on Internet is often incomplete and inaccurate (26). The knowledge that pharmacists have about herbal remedies can also be described as highly controversial (27-28). Only $35 \%$ of pharmacists who participated in the study was conducted in Estonia (29) reported that they did not have problems with delivery of herbal drugs, while $38.5 \%$ of them recognized the importance of continuing education for the appropriate delivery of herbal drugs.

Female gender, higher level of education and preferring herbal drugs compared to the other medicines were shown as factors determining the use of herbal drugs. Our results are partially compatible with the results of other authors (13-14). In the study conducted in Lebanon (13) it was shown that the use of herbal drugs and dietary supplements was associated with female gender, but also with increasing age. In the study (14) conducted in Serbia in 2011, the users of herbal drugs and herbal dietary supplements were mostly highly educated, aged 41-60, who used these preparations without previous consultation with a physician or a pharmacist.

It should be noted that our study has significant limitations. Our study included a small number of pharmacies in the territory of two geographically close municipalities. Also, in our research, we recruited patients for a short period of time (one month). All of these factors contributed to the fact that the total number of patients covered by this study is not large enough to be able to bring definitive conclusions regarding the habits and attitudes that patients in Serbia have regarding to the use of herbal drugs. However, we believe that our study offers knowledge to guide future researches. 
In conclusion, this study suggests that patients' attitude regarding herbal drugs could be dangerous, due to the serious potential of these medications to have drug-drug interactions and to the adverse effects. The failure to report the use of herbal drugs to their physicians is a particularly hazardous habit that most patients have. Due to frequent use of herbal drugs today as well as due to the the abovementioned problems, it could be said that there is an obvious need for education of both patients and pharmacists for safe and appropriate use of herbal drugs.

\section{REFERENCES}

1. Ministry of Health of the Republic of Serbia. Law on Medicines and Medical Devices. Belgrade: Official Gazette. 30/2010. (http://www.zdravlje.gov.rs/ downloads/Zakoni/Zakoni/ZakonOLekovima IMedSredstvima.pdf.) (in Serbian).

2. Tripković K, Nešković A, Janković J, Odalović M. Predictors of self-medicationin Serbian adult population: cross-sectional study. Int J Clin Pharm 2018;40:627-34.

3. Nyeko R, Tumwesigye NM, Halage AA. Prevalence and factors associated with use of herbal medicines during pregnancy among women attending postnatal clinics in Gulu district, Northern Uganda. BMC Pregnancy and Childbirth 2016;16:296.

4. World Health Organization. WHO traditional medicine strategy 2002-2005. Geneva: World Health Organization; 2002. (http://apps.who.int/iris/bitstream/ handle/10665/67163/WHO_EDM_TRM_2002.1_ eng.pdf? sequence $=1 \&$ isAllowed=y).

5. Ernst E. Herbal medicinal products during pregnancy: are they safe? Brit J Obs Gyn 2002;109:227-35.

6. Eichhorn T, Greten HJ, Efferth T. Self-medication with nutritional supplements and herbal over-thecounter products. Natural Products and Bioprospecting 2011;1:62-70.

7. Schmiedl S, Rottenkolber M, Hasford J, et al. Selfmedication with over-the-counter and prescribed drugs causing adverse-drug-reaction-related hospital admissions: results of a prospective, long-term multicentre study. Drug Saf 2014;37:225-35.

8. Eickhoff C, Hämmerlein A, Griese N, Schulz M. Nature and frequency of drug-related problems in selfmedication (over-the-counter drugs) in daily community pharmacy practice in Germany. Pharmacoepidemiol Drug Saf 2012; 21:254-60.

9. Raynor DK, Dickinson R, Knapp P, Long AF, Nicolson DJ. Buyer beware? Does the information provided with herbal products available over the counter enable safe use? BMC Med 2011; 9:94.
10. Chan K. Some aspects of toxic contaminants in herbal medicines. Chemosphere 2003; 52:1361-71.

11. Kwan D, Boon HS, Hirschkorn K, et al. Exploring consumer and pharmacist views on the professional role of the pharmacist with respect to natural health products: a study of focus groups. BMC Complement Altern Med 2008; 8:40.

12. Hasan SS, See CK, Choong CL, Ahmed SI, Ahmadi K, Anwar M. Reasons, perceived efficacy, and factors associated with complementary and alternative medicine use among Malaysian patients with HIV/AIDS. J Altern Complement Med 2010;16:11716.

13. El Khoury G, Ramadan W, Zeeni N. Herbal Products and Dietary Supplements: A Cross-Sectional Survey of Use, Attitudes, and Knowledge Among the Lebanese Population. J Community Health 2016; 41:566-73.

14. Samojlik I, Mijatović V, Gavarić N, Krstin S, Božin B. Consumers' attitude towards the use and safety of herbal medicines and herbal dietary supplements in Serbia. Int J Clin Pharm 2013;35:835-40.

15. Knotek K, Verner V, Chaloupkova P, Kokoska L. Prevalence and use of herbal products in the Czech Republic: over-the-counter survey among adult pharmacies clients. Complement Ther Med 2012;20:199-206.

16. Alkharfy KM. Community pharmacists' knowledge, attitudes and practices towards herbal remedies in Riyadh, Saudi Arabia. East Mediterr Health J 2010; 16:988-93.

17. Chrubasik-Hausmann S, Vlachojannis J, McLachlan AJ. Understanding druginteractions with St John's wort (Hypericum perforatum L.): impact of hyperforin content. J Pharm Pharmacol 2019;71:129-138.

18. Soleymani S, Bahramsoltani R, Rahimi R, Abdollahi M. Clinical risks of St John's Wort (Hypericum perforatum) co-administration. Expert Opin Drug Metab Toxicol 2017;13:1047-62.

19. Mueller SC, Uehleke B, Woehling H, et al. Effect of St John's wort dose and preparations on the pharmacokinetics of digoxin. Clin Pharmacol Ther 2004;75:546-57.

20. Bhalerao MS, Bolshete PM, Swar BD, et al. Use of and satisfaction with complementary and alternative medicine in four chronic diseases: A cross-sectional study from India. Natl Med J India 2013;26:75-8.

21. Chang HY, Wallis M, Tiralongo E. Use of complementary and alternative medicine among people with Type 2 diabetes in Taiwan: A crosssectional survey. Evid Based Complement Alternat Med 2011: 2011:983792. 
22. Vickers KA, Jolly KB, Greenfield SM. Herbal medicine: Women's views, knowledge and interaction with doctors: A qualitative study. BMC Complement Altern Med 2006;6:40.

23. Stickel F, Shouval D. Hepatotoxicity of herbal and dietary supplements: an update. Arch Toxicol 2015;89:851-65.

24. Medina-Caliz I, Garcia-Cortes M, Gonzalez-Jimenez A, et al; Spanish DILI Registry. Herbal and Dietary Supplement-Induced Liver Injuries in the Spanish DILI Registry. Clin Gastroenterol Hepatol 2018; 16:1495-1502.

25. Medagama AB, Widanapahirana H, Prasanga T. The availability and validity of safety information of over the counter herbal products for use in diabetes in Sri Lanka: A cross sectional study. Journal of Intercultural Ethnopharmacology 2015;4:264-9.

26. Scarton LA, Del Fiol G, Treitler-Zeng Q. Completeness, accuracy, and presentation of information on interactions between prescription drugs and alternative medicines: an internet review. Stud Health Technol Inform 2013;192:841-5.
27. Kwan D, Boon HS, Hirschkorn K, et al. Exploring consumer and pharmacist views on the professional role of the pharmacist with respect to natural health products: A study of focus groups. BMC Complement Altern Med 2008;8:40.

28. Spiteri M, Attard E, Serracino-Inglott A, Azzopardi LM. Compilation of a herbal medicine formulary for herbal substances in Malta and its usefulness amongst healthcare professionals. Journal of Young Pharmacists: JYP 2013;5:22-5.

29. Volmer D, Lilja J, Hamilton D, Bell JS, Veski P. Selfreported competence of Estonian community pharmacists in relation to herbal products: findings from a health-system in transition. Phytother Res 2011;25:381-6. 